\title{
Getting bad publicity and staying in power: Leviticus 10 and possible priestly power struggles
}



The story of the death of Nadab and Abihu in Leviticus 10 has always been a difficult text to understand. Recently it has been used in debates about possible power struggles between Aaronides and Zadokites in post-exilic Yehud. The article critically explores the work of three European scholars, namely Achenbach, Nihan and Otto on this issue. Initially most of the traditional questions asked by scholars are addressed such as what the 'strange fire' was, and what exactly Nadab and Abihu did wrong. The focus of the article then moves to whether Leviticus 10 reflects badly on certain priestly groups.

\section{Introduction}

The story of Nadab and Abihu and their untimely death by fire has been the subject of many academic debates. One of the important questions (and there are many others as we shall see below) usually asked has to do with the relation between Chapter 10 and the two preceding chapters. Leviticus 8 and 9 describe the ordination of the priests with an elaborate set of rituals over a period of eight days. The end result is a cultic climax described at the end of Leviticus 9, when the glory (פכָּז the Lord and consumes the עלדָ [burnt offering] and the fat on the altar. Everybody seems happy, which includes $\mathrm{YHWH}$, Moses, Aaron and his sons, whilst the people who witness the ritual are in awe (v. 24). Yet then one reads Chapter 10 and the climax changes into an anti-climax, a total 'ritual failure' as Bibb (2009:111) has described it. What is the message of this second story (Ch. 10) when read in conjunction with the first (Ch. 8-9)? Different answers have been provided depending on whether one approaches the text diachronically or synchronically. Most of these issues will be revisited below, but the article sets it sights on a slightly different although far more murky debate, namely the possible power struggles between the Aaronide and Zadokite ${ }^{2}$ priestly groupings in post-exilic Yehud.

The question asked here is whether Chapter 10 reflects badly on any specific priestly group? If it does, is it aimed at the Aaronides or Zadokites? Is it possible to understand Leviticus 10 as proZadokite propaganda? Or, maybe pro-Aaronide propaganda? In order to facilitate the discussion I will be engaging with the recent work of Achenbach (2003) and Nihan (2007) and to a lesser extent Otto (2009b). These scholars are all part of what Stackert (2009:195) has described as the 'redaktionsgeschichtliche Schule of much German-language ${ }^{3}$ Torah scholarship.' Both Achenbach and Nihan agree, for instance, that Leviticus 10 is a very late text in the book of Leviticus and both construct a similar relation with Numbers 16-17. Both are also interested in the relation with Ezekiel 44, but they differ on the important issue of whether Leviticus 10 is pro-Aaronide or proZadokite.

\section{Achenbach}

Achenbach's (2003:93-110) engagement with Leviticus 10 is part of a broader discussion of Numbers 16-17 (2003:37-140). He starts by acknowledging (like many other scholars) that the Leviticus 10 chapter did not originally form one unit with Leviticus 9. The contrast between 10 and 9 is simply too great. Achenbach (2003:93) describes Leviticus 10 as the legend of Nadab and Abihu, the purpose of which is to make readers recognise the scandalous arbitrariness (skandalöse Eigenmächtigkeit) of the Aaronides. Readers should also experience this narrative as the greatest catastrophe in the history of Israel's cult. For Achenbach (2003:94) the relation between Leviticus

1.Hundley (2011:55) argues that joy is a seemingly ubiquitous feature' when it comes to the dedication of temples in the Bible and the Ancient Near East. He refers to the dedication of the temple in 1 Kings 8 and examples from Mesopotamia, Egypt and Ugarit.

2.See the overviews provided by Fabry (2004:201-206) and Grabbe (2003:205-208). In terms of post-exilic texts, both point out that we read of the Aaronides in priestly texts in books such as Exodus, Leviticus and Numbers. The Zadokites are found in texts such as Ezekiel 40:46; 43:19; 44:15 and 48:11, where they are distinguished from the Levites.

3.Nihan is French speaking, but still fits well into this school. 
10 and 9 is similar to the relation between Exodus 32 and Exodus 24, where Aaron basically goes from hero to zero in the eyes of the readers. ${ }^{4}$ Since Leviticus 10 is thus about proclaiming the shame and failure of the Aaronides, it must be from a later and different hand of priestly decent, a different 'Trägerkreis' which wanted to counter the legend of the priestly Aaron of Chapter 9. In short, Leviticus 10 becomes a pro-Zadokite text which rubbishes the ability of the Aaronides to do the cultic job.

Before making the connection with the Zadokites, Achenbach (2003:94-96) engages with the diachronic relationship to other chapters in the Pentateuch such as Numbers 16 and Exodus 30:1-9. Numbers 16 is about legitimising the Aaronide priestly dynasty, which involves censers and incense. Exodus 30 has to do with incense burning, ${ }^{5}$ which relates it to Numbers 16 and Leviticus 10. Leviticus 10 is supposedly younger than both texts. For Achenbach (2003:96) the offering of incense is probably the result of Persian influence.

At the centre of the Nadab-Abihu legend is the motif of the strange fire (see Achenbach 2003:96-97). They die because there is something wrong with the fire. The problem for Achenbach (2003:96-97) is, firstly, that the sons of Aaron were unauthorised to do this, since it was Aaron's prerogative as high priest to bring incense, as is clearly stated in Exodus 30:1-9. The 250 lay persons are killed in Numbers 16, because they are also not authorised to bring incense. The text furthermore establishes a bridge between Exodus 30:8-9 and Leviticus 16:12-13, where it is said that the fire must come from the altar. Thus the second problem is that the fire came from somewhere else. After providing an overview of the practice of keeping the fire pure in Zoroastrianism, Achenbach (2003:100-101) argues that the message of Leviticus 10:1-3 is the failure of the two eldest sons of Aaron at the first sacrificial event in the cultic history of Israel.

Achenbach (2003:102-105) also engages with the issue of why Aaron's other two sons may not mourn their brothers in light of the fact that this is allowed in Leviticus 21:1-3. He (Achenbach 2003:106) argues that the real surprise lies in the 'Priestertora' that follows the interruption of the ritual. YHWH speaks only to Aaron, something which happens only here and in Numbers 18, but the word spoken to Aaron is reminiscent of Ezekiel 44:20-27 and not so much of Leviticus 21. For Achenbach the origins of these two texts (i.e. Ezk 44 and Lv 21) lie in a similar tradition, but

4.For an opposite reading of Exodus 32 and 24 see Watts (2011:417-430), who argues that Exodus 32 does not actually reflect that badly on Aaron. Watts, though, has a totally different view of the Aaronides in the Second Temple Period. As we will see later, he thinks that the Aaronides were basically in charge during the Second Temple Period. Achenbach holds a different view.

5.See Jürgens (2001:274-279) for an overview of the development of the use of incense in worship in Israelite religion.

6. Following his overview of the role of fire in Zoroastrianism (Achenbach 2003:9899), Achenbach $(2003: 100)$ asks in which way the influence of Zoroastrianism is apparent in the idea of the 'strange fire' idea. He rejects Laughlin's (1976) view that the strange fire points to some, attempt to introduce a Zoroastrian ritual into the temple. It seems to be more a case of: if God, whom Achenbach calls the 'theophane Heilige', is present in the fire, then any strange fire from another source can only be rejected. There is also something counter-Persian in the representation of YHWH being present in a fire column and moving with his people and their army. The fire column presents a kind of alternative reality. now Leviticus 10 reverts back to Ezekiel 44. For him there are more similarities between the priestly torot in Leviticus 10 and Ezekiel 44 than between Leviticus 10 and 21. One example (Achenbach 2003:106) is the law about staying sober, which is slightly more elaborate in Leviticus 10:9 than in Ezekiel 44:21. Furthermore, Ezekiel 44 is based on the priests in the Gola and they follow the tradition of the Zadokites. Another similarity between Leviticus 10 and Ezekiel 44 is the command to distinguish between holy and profane, and pure and impure. This is from Ezekiel 44:23. Achenbach then puts it as follows (2003:108): 'Die enge Anlehnung an die Torot von Ez 44, 20-23 belegt, daß die Abfassung des literarisch einheitlichen Kapitels Lev 10 unter dem Einflu $\beta$ zadoqidischer Kreise der Gola stand.'

Ezekiel $40-48$ is the only collection of texts that refers to the 'sons of Zadok' (בְני־צָדוֹק) in the whole of the Old Testament. Achenbach thus sees a Zadokite hand in the last redaction of Leviticus 10, which is meant to discredit the Aaronides. Leviticus 10 functions similar to 1 Samuel 2:4, which questioned the competence of the sons of Eli, but now the competence of the Aaronides is questioned by this Zadokite author of Leviticus 10 (Achenbach 2003:110). In Achenbach's understanding Leviticus 10 is thus a pro-Zadokite and antiAaronide text.

Achenbach (2003:110-123) also has a fairly elaborate genealogical argument based on Exodus 6:14-27 about the two surviving sons of Aaron, namely Ithamar and Eleazar. Eleazar dies in Joshua 24:33 and seems to be followed by his son Phinehas (Jdg 20:28). Ithamar is mentioned in the rest of the Pentateuch, ${ }^{8}$ but then disappears. Yet in Ezra 8:2 Phinehas and Ithamar are mentioned together. Along with Blenkinsopp (1998), Achenbach is certain that there are connections between Ezra 8:2 and Leviticus 10. Achenbach (2003:119) also seems to agree with Blenkinsopp ${ }^{9}$ that these texts (along with 1 Chr 24:1-19) point to both conflict between Aaronides and Zadokites and eventual compromise. ${ }^{10} \mathrm{He}$ then adds:

Allerdings wäre Lev $10 \mathrm{zu}$ optimistich interpretiert, wenn es nur um die positiven Legitimationsinteressen der Zadokiden ginge.

Der polemische Grundton des Textes geht weiter: Er strebt auf

7 See the overview by Dozeman (2009:168-175) of this pericope. Dozeman emphasises that only in the case of Eleazar is a son (namely Phinehas) mentioned. Phinehas is the only one who represents the sixth generation after Levi. Dozeman (2009:172) argues that 'when read against the background of the exile, Phinehas, the sixth generation, represents the postexilic community, since the fourth and fifth generations are those who undertake the wilderness journey, which signifies the experience of the exile.' Dozeman does not mention the fact that it is this line of Eleazar and Phinehas which becomes the Zadokite line in texts from 1 Chronicles. See (in MT) 1 Chronicles 5:29-34; 6:35-38 and 24:1-3.

8.See Exodus 6:23; 28:1; 38:21; Leviticus 10:6, 12, 16; Numbers 3:2, 4; 4:28, 33; 7:8 and 26:60.

9.Achenbach (2003:119) is not really convinced by Blenkinsopp's (1998:34-37) argument that the origins of the Aaronides probably lie in Bethel. See also Jürgens (2001:271-272), who finds Blenkinsopp's arguments plausible but still unconvincing, (2001:271-272), who finds Blenkinsopp's arguments pla
since there is no archaeological evidence to support it.

10.In 1 Chronicles 24:3 it is said that Zadok was one of the sons of Eleazar. Zadok is thus written into the line of Aaron. See also Blenkinsopp (1998:39), who argues that 'the progress of the Aaronides to a position of power and privilege in Jerusalem was marked by conflict and was concluded with accommodation between Aaronide priests and Zadokite priests. 
eine Desavouierung der Hegemonialansprüche derjenigen, die die Aarongeneologie als primäre Legitimationsgrundlage ihrer Ansprüche in Anschlag gebracht hatten. (Achenbach 2003:119)

It seems as if he is taking a step backwards now, since he acknowledges that this narrative actually reflects badly on any priestly group which views itself as descendants of Aaron. Does this mean that if 1 Chronicles 24:1-19 traces Zadok as a descendent of Eleazar, then the Zadokite lineage is also tainted by the cultic failure described in Leviticus 10? Achenbach seems reluctant to say this outright, but his arguments leave this possibility open. This brings us to another scholar who interprets Leviticus 10 differently and in favour of the Aaronides.

\section{Nihan}

Nihan follows Achenbach when it comes to the most important historical-critical issues. For Nihan (2007:576607) Chapter 10 is the last chapter added to Leviticus and he follows Achenbach when it comes to interpreting this text in relation to Numbers 16-17. Leviticus 10 was written after that text was finalised and all three layers were already united into one narrative. Thus in terms of what is often called diachronic issues the two are broadly in agreement, but Nihan's interpretation of what the significance of this narrative is for Aaron and his descendants is totally different from Achenbach's.

Nihan (2007:576-579) starts by offering some ideas on the structure of the chapter and argues that the text is not as disjointed as historically-oriented critics have claimed before him. ${ }^{11}$ For Nihan (2007:578) Leviticus 10 has a 'clear narrative progression' and he also identifies (following Hartley 1992:129 \& Staubli 1996:85) a chiastic structure in the chapter which could be summed up as follows:

A. 10:1-5 Transgression of cultic laws by Aaron's elder sons, sanctioned.

B. 10:6-7 Instruction by Moses to Aaron and his two remaining sons

X. 10:8-11 Instruction by Yahweh to Aaron alone

B'. 10:12-15 Instruction by Moses to Aaron and his two remaining sons

A'. 10:16-20 Transgression of cultic laws by Aaron's younger sons, not sanctioned. (Nihan 2007:579)

Previously Leviticus 10:12-15 and 10:16-20 had been regarded as belonging to a later layer, but for Nihan (2007:577-578) despite the fact that they take us back to the previous chapter and beyond what happened in 10:1-5, the chapter could still be read as one.

Like many other scholars before him, Nihan (2007:580-583) also asks what אָש זָخָרה [strange fire] refers to and, of course, what Nadab and Abihu did wrong? For Nihan (2007:582) the answer lies in verse 1 in the clause 'it was not commanded by Yahweh.' The ritual performed by Nadab and Abihu was that the chapter 'fehlt thematisch wie stilistisch jede Einheitlichkeit.' not commanded in the first nine chapters of Leviticus and that raises the question why censer-incense offering is not mentioned in these chapters. The answer (for Nihan) lies in the other two texts in the Pentateuch which refer to censers being used in worship: Leviticus 16:12-13 and Numbers 17:6-15. These two texts state that the only person who could execute this ritual was the high priest. In this regard Nihan does not differ much from Achenbach. Nihan (2007:584) continues that Leviticus 10 and Numbers 16-17 share this doctrine that censer-incense offering is 'a privilege reserved for the high priest' and that Leviticus 10 anticipates the story of Numbers 16-17. ${ }^{12}$ Nihan (2007:585) also acknowledges that the editors of the Torah had to address the issue of censer-incense offering because of the growing popularity 'of this type of offering in Persian-period Yehud.' For Nihan (2007:585) there is a clear connection between Leviticus 16:12-13, Leviticus 10 and Numbers 16-17, since 'in the entire Torah only these three passages mention censer-incense.'

Furthermore, for Nihan (2007:586), when the story of Nadab and Abihu is read in the context of Leviticus 1-10, it becomes a didactic story the objective of which is to teach the 'necessity of complete observance of Yahweh's laws, as well as the consequences of disobedience.' In this regard he follows Levine (1989:38).

It is safe to say that up to now Nihan agrees to a large extent with Achenbach. The strange fire incident had something to do with the fact that only the high priest was allowed to bring incense offerings. Nihan also acknowledges some Persian influence, but he is much more careful in this regard than Achenbach. Nihan differs from Achenbach about the fact that the fire was not from the altar. For Nihan (2007:581) this issue is really not that significant. With regard to the diachronic issues of how Leviticus 10 is related to Numbers 16-17 and other relevant texts in the Pentateuch, they are mostly in agreement.

One of the main differences between Achenbach and Nihan has to do with the way in which they portray the dynamic between Leviticus 10 and the priestly torot in Ezekiel 44:20-23. This discussion is obviously about Leviticus 10:8-11, which is in the middle of the chiastic structure identified above and is one of only two texts in the Pentateuch where Aaron is directly addressed by $\mathrm{YHWH}$ and Moses is excluded. Nihan (2007:592) carefully analyses the differences between 10:8-11 and Ezekiel 44 and argues that 'in two respects, Lev 10 goes beyond Ez 44.'

Firstly Nihan (2007:592) argues that in Ezekiel 44:21 we find the command that priests need to be sober when they perform their duties and in verse 23 we find the command that priests are to teach (ירה Hif) the difference between holy and profane and to show (ידעי Hif) the difference between

12.Nihan (2007:584-585) notes that one would have expected that the sons of Aaron's older brother would have removed the bodies of Nadab and Abihu. This means his brother Yizhar, but his first son is Korah, who is one of the culprits in Numbers 16. The fact that the sons of Aaron's younger brother Uzziel are called upon to do this means, that the author already knows that Korah is out of the loop. For Nihan Leviticus 10 is thus contemporary with or later than the last edition of Numbers $16-17$. 
clean and unclean. Verses 9 and 10 of Leviticus 10 are similar, with the former providing the command to be sober and the latter commanding Aaron to distinguish (בדל Hif) ${ }^{13}$ between holy and profane, and clean and unclean. For Nihan the main difference is that there is a causal ${ }^{14}$ relationship between these two verses which is clearly absent from Ezekiel 44 . The priests are to be sober in order to distinguish (v. 10) and teach (in v. 11). For Nihan (2007:592) this 'betrays an on-going reflection on the basic categories of priestly thinking, in this case the nature of holiness and its opposition to altered states of consciousness' and in that sense Leviticus 10 goes beyond Ezekiel 44.

Nihan's (2007:592-593) second argument has to do with verse 11 and the fact that Aaron is now commanded to teach (again ירה Hif) to all of Israel the decrees which Yahweh conveyed to them through Moses. This goes beyond Ezekiel 44:24, where priests are only asked to keep (שמר) the laws. Yet for Nihan this teaching does not only entail cultic matters, but 'the Torah in general' and in that sense Leviticus 10 goes well beyond Ezekiel $44 .{ }^{15}$

Nihan's (2007:598-602) interpretation of Leviticus 10:16-20 is also important for our discussion. This pericope was not discussed in Achenbach's engagement with the text. The text presents an argument between Moses and Aaron about the interpretation of the law, an argument which Aaron apparently wins. This pericope goes back to what happened in Leviticus 9 and even further to a discrepancy between Leviticus 6:23 and 6:19. For Nihan (2007) the problem is once again that the priests have seemingly not obeyed the law:

We thus return to the very issue with which the story of ch. 10 opened, the righteousness of the Aaronides; the parallel is enhanced by the fact, noted above, that Moses accuses not Aaron himself but his remaining sons, Eleazar and Ithamar. (p. 599)

The Aaronides are thus under threat again. Moses investigates (דרש) and finds that they have not acted in accordance with Leviticus 6:19 and as he had commanded. Yet Aaron responds with an answer which is not that clear, but the end result is that Moses acknowledges that Aaron is correct. For Nihan (2007:601-602) we have a dispute here between Moses and Aaron about interpreting the laws, one which is clearly won by Aaron. Aaron is transformed into a teacher

13.Liss (2008:348) argues that the act of separation here becomes an act of imitating God. This was what God did in the Priestly creation narrative and now priests are asked to follow suit. It is tempting to argue along with Nihan above, that this is another example of Leviticus 10 going beyond Ezekiel 44 by portraying the vocation of the priests in much stronger terms; they are after all imitating God himself now, something which one does not find in Ezekiel 44 . Unfortunately for this argument, the stem (בדל Hif) is found in Ezekiel 22:26, in which the priests are criticised for not distinguishing between impure and pure.

14.See the discussion by Jürgens (2001:289) and how the infinitivus constructus is used here at the start of both verses 10 and 11 .

15.Nihan (2007:593-595) argues for the more general meaning of torah in the light of the usage of $7 \pi$ in Leviticus 10:11. The term is very uncommon in 'priestly' portions of the Pentateuch and probably refers to Leviticus $26: 46$. By referring to texts such as Deuteronomy 24:8, Ezekiel 22:26, Zephaniah 3:4 and Haggai 2:11, Nihan argues that traditionally priestly roles were defined in a rather narrow cultic sense of needing to determine what is clean and what is unclean. Leviticus 10:11 extends the role of priests to teachers of the Torah in general. of the law as already proclaimed by YHWH in verse $11 .{ }^{16}$ In conclusion, Nihan (2007:602-605) interprets Leviticus 10 as the 'Founding Legend of Priestly Exegesis'. In this chapter Moses acts as an exegete of the law (vv. 12-15), but is then surpassed in the next pericope by Aaron, who interprets the laws better than Moses does.

The question is thus whether Aaron and the Aaronides really end up in a worse position after the Nadab and Abihu incident as Achenbach would have us believe? Aaron loses a lot, but also seems to gain some more. For the first time in the Sinai narrative YHWH addresses him directly with a very potent command. Furthermore, Aaron wins an exegetical argument with Moses. This last pericope was unfortunately totally ignored by Achenbach.

\section{Otto}

In a fairly extensive critical response to Nihan's work Otto (2009b:107-142) ${ }^{17}$ offers a fair amount of criticism in which he supports Achenbach's original conclusions. The following insights are the most important.

Otto (2009b:117) agrees with Nihan and Achenbach that Leviticus 10 was produced by a 'postpentateuchredaktionelle theokratische Bearbeitung', but he is not impressed with Nihan's understanding of Leviticus 10 as a 'late literary unity' ${ }^{18}$ For Otto (2009b:117-118) one could argue that 10:1-7 and 16-20 are late (post-P), but the connection with 10:8-11 is superficial. Furthermore, Otto believes that 10:12-15 is older and should be read along with verses $8-11$ as well as with Leviticus 9 which is about the ordination of the Aaronides. For Otto (2009b) verses 1-7 and 16-20 were added later by a theocratic redaction of the Zadokites with the following purpose:

Der theokratischen Bearbeitung der Zadokiden, die die Pentateuchredaktion voraussetzt, geht es mit der Rahmung von Lev 10, 8-15 durch Lev 10, 1-7.16-20 darum, die dort in Nachtrag zu Lev 8-9 unterstrichene Autorität der Aaroniden auf die Zadokiden umzulenken, die nun eine Auslegungskompetenz in Kultfragen unabhängig von der des Mose erhalten. (pp. 118-119)

In Otto's view, the Zadokites edited this chapter so that the authority of the Aaronides could be channelled in their direction. What he means by this is that the Zadokites traced their ancestry via Eleazar, and although Chapter 10 as a whole seems pro-Aaronide, it is actually attempting to be pro-Zadokite. In other words, since Nadab and Abihu as the 'original' Aaronides handled things ineptly, Eleazar and Ithamar had to save the day - and the Zadokites are descendants of Eleazar. Whatever positive images of the Aaronides one thus sees in Leviticus 10 have all been coopted in favour of the Zadokites. These arguments are thus also thoroughly genealogical in nature. Thus, as we saw 16.See also similar conclusions reached by Watts (2007:97-129).

17.Otto's chapter was originally published in 2008 in Zeitschrift für Altorientalische und Biblische Rechtsgeschichte 14, 366-407 under the same title of Das Buch Levitikus zwischen Priesterschrift und Pentateuch. The article is about Nihan's entire book and only about 5 pages (pp. 117-121) are directly applicable to our debate.

18.For a shorter English discussion of Nihan's work, see Otto (2009a:135-156). 
earlier, Achenbach argued this by means of the genealogy in Exodus 6:14-25. ${ }^{19}$ In later texts the Zadokites are presented as descendants of Eleazar. ${ }^{20}$ One problem with the genealogical argument, which is also applicable to what Achenbach was saying, is the fact that the only texts which explicitly trace Zadok via the Eleazar/Phinehas line are from 1 Chronicles. Without these texts one could not have imagined any link between Zadok and Aaron. Otto is just reading backwards from later texts into earlier texts when he argues for undercover Zadokites in Leviticus 10.

In short, this is a fascinating argument by Otto, but it seems a bit speculative. It also means that Otto apparently agrees with Nihan that the final form of the chapter reflects positively on whichever priestly group is behind the chapter. For Nihan it is the Aaronides and for Otto the Zadokites, although the latter in a way sneaked in under the cover of darkness. This might be seen as being in tension with the interpretation of Achenbach, but Achenbach focused more on the first half of Chapter 10 and says basically nothing about the second half. It is clear that Otto would agree with this, but this part is aimed at the Aaronides, whereas the second part where Aaron gets a direct word from $\mathrm{YHWH}$ and wins an exegetical argument with Moses is more propaganda for the Zadokites.

One aspect of this argument is particularly unconvincing. If Eleazar is the forefather of the Zadokites (and $1 \mathrm{Chr}$ would agree with that), the text is still very clear that he also did something wrong. Verses 16-20 are quite adamant that Eleazar and Ithamar also did something wrong. Who saves the day for them? Their father, Aaron! He wins the argument with Moses. How could this text be anti-Aaronide as Otto would want us to believe? Even if added later it still underlines the fact that Aaron was in a better position and his younger sons were alive, because he won an argument with Moses.

\section{Discussion}

At the start of this article I mentioned that one of the questions addressed would be whether one could argue that what happened in Leviticus reflected badly on any specific priestly group. To this question Achenbach and Otto would have answered in the affirmative. For them the narrative reflects badly on the Aaronides. Achenbach thought that it was a critique of the Aaronides, although towards the end he acknowledged that the story could be aimed at any priestly group. Achenbach also focused only on the first half of the text. Otto focused on the second half and saw undercover propaganda for the Zadokites and in that sense the text is anti-Aaronide. Nihan clearly disagrees. Yet it is not as simple as reading texts and deciding on either their final form, or their supposed development that they are for or against a

19.The important verses here are 23 , which names the sons of Aaron, and 25 , which refers to Eleazar and his son Phinehas.

20.See Otto (2009a:148), who argues that 'for the Aaronides, according to the narrative of the Pentateuch, an unbroken continuity exists from Aaron as Moses' brother in Egypt and at Mount Sinai on to Pinhas [sic] (Num 25, 10-12) as the ancestor of the Zadokites (1 Sam 14, 3; 2 Sam 8, 17; 1 Chr 5, 33; 6,37-38; 18, 16)' These verses from Chronicles are most convincing, since they all portray Zadok as These verses from Chronicles are most convincing, since they all portray Zadok as
a descendent of Aaron via Eleazar. With regard to 1 Chronicles 5:33 (MT) the next verse should also be added. certain group. One problem with this whole debate is that we really do not know who these groups were in post-exilic Yehud. And for that matter the pre-exilic period might be even vaguer. The Aaronides seem to be present in what has traditionally been called P. ${ }^{21}$ As Watts (2007:143) puts it: 'The Hebrew Bible does not, however, depict Aaronide priests as maintaining such a cultic monopoly, or even holding positions of unequalled prominence, for much of Israel's history'.

\section{Or has Blenkinsopp (1998) has said:}

Anyone attempting to understand the Judean priesthood in its historical development has to take seriously the fact that, apart from Priestly material $(\mathrm{P})$ and Chronicles, ${ }^{22}$ our sources are silent both on Aaronide priests and on Aaron as their priestly eponym. (p. 37)

Thus when it comes to the Aaronides our sources are fairly silent. It would be better to talk of the literary Aaronides, who seem to inhabit only texts from the exilic/post-exilic period. If they are then only a post-exilic phenomenon, the question has always been where did they come from? Otto (2003:16481649) has, for instance, proposed that the Aaronides were a reform movement that splintered off the Zadokites in the exilic period..$^{23}$ The Aaronides are the authors of what has traditionally been called P.

Blenkinsopp (1998:34-39) has argued that the Aaronides should be linked to the cult at Bethel in the exilic period and that their roots go back to the sanctuary in the Northern Kingdom during the pre-exilic period. Others like Grabbe (2003:208), Achenbach (2003:119) and Schaper (2000:269$279)^{24}$ seem to agree. Still, their pre-exilic roots are not that clear from the descriptions in the Hebrew Bible and our sources are on the whole silent about this time period and the origins of the Aaronides.

But then if we move to the Zadokites, things do not look much better. Recently Hunt (2006) ${ }^{25}$ has described them as 'missing'. 'Zadok first appears' as Grabbe (2003:206) puts it, 'without father or mother or genealogy, in 2 Samuel 1:24-36.' Yet the only place in the Bible where we find reference to the 'sons of Zadok' similar to the 'sons of Aaron' in Leviticus is obviously in Ezekiel. Still, some scholars ${ }^{26}$ would argue that the Zadokites were the ones who actually served as priests in Judah until 586 BCE. One is tempted to say that scholars postulate a power struggle between the Aaronides,

21 In the European redactional school of which Achenbach Nihan and Otto are all members, things are more complicated than this. In some of these debates one often finds reference to $P^{G}, P^{S}$ and quite a few post- $P$ layers. These are all from often finds reference to $\mathrm{P}^{6}, \mathrm{P}^{\mathrm{s}}$ and quite a few post-P layers. These
priestly circles and we find them in Exodus, Leviticus and Numbers.

22.See also Otto (2003:1648), who mentions that a problem with the Aaronides is that 'es keine gesicherten vorexilische Belege gibt.'

23.See also Otto (2007:180-182) for a further overview.

24.Schaper (2000:276-277) actually offers a much more complicated picture in which three to four groups of priests were eventually unified in the Achaemenid period. He calls one of these groups the 'Betheler Aaroniden'.

25. Hunt (2006:190) actually comes to the conclusion that the Zadokites did not exist before the Hasmonean period.

26.See, for instance, Otto (2007:180-182), Schaper (2000:270) and Fabry (2004:202). For Otto (2007:180-181) the Zadokites needed to include themselves in the genealogy of Aaron simply because the Davidic kings who gave them their position of privilege were no more. 
about whom the sources are 'silent', and the Zadokites, who are 'missing'. This statement exaggerates a bit, but it points to the fact that Old Testament criticism has struggled with this issue for more than a hundred years. ${ }^{27}$ We are not close to any consensus on this. It is, as is often said, not that straightforward to move from the text to the world behind the text.

What we do have is a text such as Leviticus 10, where Aaron and his sons are mentioned. These people are clearly priests and they perform rituals, one of which goes wrong. We are not entirely sure what went wrong, but Achenbach and Nihan are probably correct that they did something which only Aaron was supposed to do. Does this reflect badly on them? Yes, probably, but as Achenbach later acknowledged, the narrative acts as a kind of criticism against any priestly group which claimed to be descendants of Aaron. Thus, if Achenbach and Otto were correct that the Zadokites had the last say in the chapter and were sort of hidden behind the text, the Zadokites were clearly shooting themselves in the foot.

But then Nihan has argued that Aaron is basically better off after everything that went wrong, since Yahweh speaks to him directly and gives him a command which entails the power to distinguish (10:10) and the power to teach (10:11). Later Aaron gets the upper hand in an exegetical argument (10:1620) with Moses, which, by the way, is another text which we do not really understand. Thus after the catastrophe Aaron seems to be in a stronger position. After discussing Leviticus 8-10 Watts (2007) ${ }^{28}$ comes to the following conclusion:

The fact that the reader/hearer cannot understand either the nature of the danger in 10:1-3 or the logic of the [sic] Aaron's ruling in 10:16-20 only increases the mystique of the priestly office. Summarized in a more modern idiom, the message from the Aaronide priests to the congregation of Israel in Leviticus 10 is this: 'We are professionals doing a necessary and dangerous job, and only we can do it right.' (p. 129)

The chapter thus ends enhancing the power of the priests. Watts is convinced that they were Aaronides and that the Aaronides dominated the Second Temple Period. Scholars like Otto and Achenbach would strongly disagree in favour of the Zadokites, although I have pointed out that there are parts of the arguments of both that are not entirely convincing. Blenkinsopp (1998:39) argues for 'accommodation' between the groups and the genealogies quoted above from 1 Chronicles clearly point that way. I do not think that we really know. We do know that these priests were powerful and that they had a privileged position in the Second Temple Period, especially in light of the fact that the kings were no more. We also think that they were the ones who compiled

27.See especially the overview offered by Hunt (2006:13-49).

28.Watts's interpretation is not that different from Nihan's, since he also concludes that Chapter 10 benefits Aaron. He does not, like Nihan, offer an explanation of what was wrong with the 'strange fire'. For Watts (2007:117) it is not possible 'to explain exactly why Nadab and Abihu's incense offering was wrong or exactly how Aaron reasoned regarding the eating of the sin offering' since this would 'spoil the mystery of priestly service.' the Pentateuch. The Pentateuch as such is partly there to reinforce their position of privilege.

The only other certainty we have is that they were not Levites. It is clear that 'Zadokite' texts such as Ezekiel 44:10 27 regard the Levites as second-class priests who have to play a lessor role. One finds a similar view of the Levites in an 'Aaronide' text such as Numbers 16-17, which both Nihan and Achenbach would agree is presupposed by Leviticus 10 . In Ezekiel 44 and Numbers 16-17 there are only two groups of priests, namely the Zadokites or Aaronides, over against the Levites. They are not even mentioned in Leviticus 10, but maybe the story also had a message for the Levites similar to what Watts claimed above. One could thus argue that later, after the 'Vereinigung' that Schaper (2000:277) argues for, had already taken place and after the mentioned texts from 1 Chronicles were written, Leviticus 10 might have been read as propaganda for the newly formed combined Aaronide and Zadokite priestly group. This one group, who now all go back to the same ancestor, Aaron, is presented as the priestly group who have the legitimacy to do the dangerous cultic job. Still before this 'Vereinigung' I would think that Leviticus 10 was pro-Aaronide and I find the arguments presented by Nihan (and also Watts) more convincing than those presented by Achenbach and Otto.

Yet apart from the cultic vocation they also became (as Nihan has convincingly shown) the true interpreters of the Torah of Moses. Their ancestor wins an exegetical argument with Moses. They as priests have the right and calling to teach and interpret the Torah.

\section{Acknowledgements Competing interests}

The author declares that he has no financial or personal relationship(s) which may have inappropriately influenced him in writing this article.

\section{References}

Achenbach, R., 2003, Die Vollendung der Tora: Studien zur Redaktionsgeschichte des Numeribuches im Kontext von Hexateuch und Pentateuch, Harrassowitz Verlag, Wiesbaden. (Beihefte zur Zeitschrift für Altorientalische und Biblischer Rechtsgeschichte, 3)

Bibb, B.D., 2009, Ritual words and narrative worlds in the book of Leviticus, T \& T Clark, London. (Library of Hebrew Bible/Old Testament Studies, 480).

Blenkinsopp, J., 1998, 'The Judean priesthood during the Neo-Babylonian and Achaemenid periods: A hypothetical reconstruction', Catholic Biblical Quarterly $60,25-43$.

Dozeman, T.B., 2009, Commentary on Exodus, Eerdmans, Grand Rapids. (Eerdmans Critical Commentary).

Fabry, H-J., 2004, 'Zadokiden and Aaronided in Qumran', in F-L. Hossfeld \& L. Schwienhorst-Schönberger (eds.), Das Manna fällt auch Heute noch. Beiträge zur Geschichte und Theologie des Alten, Ersten Testaments: Festschrift für Erich Zenger, pp. 201-217, Herder, Freiburg. (Herders Biblische Studien, 44).

Gerstenberger, E.S., 1993, Das 3. Buch Mose. Leviticus, Vandenhoek \& Ruprecht, Göttingen. (Das Alte Testament Deutsch, 6).

Grabbe, L.L., 2003, 'Were the pre-Maccabean high priests 'Zadokites'?, in J.C. Exum \& H.G.M. Williamson (eds.), Reading from right to left: Essay on the Hebrew Bible in honour of David J.A. Clines, pp. 205-215, Sheffield Academic Press, Sheffield. (JSOT suppl. ser. 373).

Hartley, J.E., 1992, Leviticus, Word, Dallas. (Word Biblical Commentary).

Hundley, M.B., 2011, Keeping heaven on earth, Mohr Siebeck, Tübingen. (Forschungen zum Alten Testament, 2. Reihe, 50).

Hunt, A., 2006, Missing priests: The Zadokites in tradition and history, T \& T Clark, London. (Library of Hebrew Bible/Old Testament Studies, 452). 
Jürgens, B., 2001, Heiligkeit und Versöhnung: Levitikus 16 in seinem literarischen Kontext, Herder, Freiburg. (Herders Biblische Studien, 28).

Laughlin, J.C.H., 1976, 'The strange fire of Nadab and Abihu', Journal of Biblical Literature 96, 559-565. http://dx.doi.org/10.2307/3265571

Levine, B.A., 1989, The JPS Torah commentary: Leviticus, The Jewish Publication Society, New York. (The JPS Torah Commentary).

Liss, H., 2008, 'Ritual purity and the construction of identity: The literary function of the laws of purity in the book of Leviticus', in T. Römer (ed.), The books of Leviticus and Numbers, pp. 329-354, Uitgeverij Peeters, Leuven. (Bibliotheca Ephemeridum Theologicarum Lovaniensium, 240).

Milgrom, J., 1991, Leviticus 1-16: A new translation with introduction and commentary, Doubleday, New York. (Anchor Bible Commentary).

Nihan, C., 2007, From priestly torah to Pentateuch, Mohr Siebeck, Tübingen. (Forschungen zum Alten Testament 2. Reihe, 25).

Otto, E., 2003, 'Priestertum II, Religionsgeschichtlich 1., Alter Orient und Altes Testament', in H.D. Betz, D.S. Browning, B. Janowski \& E. Jüngel (eds.), Religion in Geschichte und Gegenwart, 4. Aufl., Bd. 6, pp. 1646-1649, Mohr Siebeck, Tübingen.

Otto, E., 2007, Das Gesetz des Mose, Wissenschaftliche Buchgesellschaft, Darmstadt.
Otto, E., 2009a, 'The holiness code in Diachrony and Synchrony in the legal hermeneutics of the Pentateuch', in S. Schectman \& J.S. Baden (eds.), The Strato of the Priestly Writings: Contemporary Debate and Future Directions, pp. 135156, Theologischer Verlag Zürich, Zürich. (Abhandlungen zur Theologie des Alten und Neuen Testaments, 95)

Otto, E., 2009b, Die Tora. Studien zum Pentateuch. Gesammelte Aufsätze, Harrassowitz Verlag, Wiesbaden. (Beihefte zur Zeitschrift für Altorientalische und Biblischer Rechtsgeschichte, 9)

Schaper, J., 2000, Priester und Leviten im achämenidischen Juda, Mohr Siebeck, Tübingen. (Forschungen zum Alten Testament, 31).

Stackert, J., 2009, 'The holiness legislation and its Pentateuchal sources: Revision, supplementation, and replacement', in S. Schectman \& J.S. Baden (eds.), The strata of the priestly writings: Contemporary debate and future directions, pp. 187-201, Theologischer Verlag Zürich, Zürich. (Abhandlungen zur Theologie des Alten und Neuen Testaments, 95).

Staubli, T., 1996, Die Bücher Levitikus, Numeri, Verlag Katholisches Bibelwerk, Stuttgart.

Watts, J.W., 2007, Ritual and rhetoric in Leviticus: From sacrifice to scripture, Cambridge University Press, Cambridge. http://dx.doi.org/10.1017/СВ09780511499159

Watts, J.W., 2011, 'Aaron and the golden calf in the rhetoric of the Pentateuch', Journal of Biblical Literature 130(3), 417-430. 